\title{
Etikus vezetés, egy kutatás kezdetén
}

\section{Ethical leadership, at the beginning of a research}

\author{
E. BARIZSNÉ HADHÁZI \\ Debreceni Egyetem, Gazdaságtudományi Kar, Vezetés- és Szervezéstudományi Intézet, Vezetéstudományi \\ Tanszék, barizsne.hadhazi.edit@econ.unideb.hu
}

\begin{abstract}
Absztrakt. Jelen tanulmányban az etikus vezetés témakörét járom körbe. Betekintést nyújtok az etikus vezetés megközelítési lehetôségeibe, irodalmi áttekintést adok az etikus vezetés fogalmáról, bemutatom a témakörhöz kapcsolódó legfontosabb empirikus kutatásokban alkalmazott mérési módszereket. Kísérletet teszek arra is, hogy egy kutatás első eredményeiről beszámoljak: egy kisebb minta adatainak elemzésén keresztül próbálok képet kapni a magyar vezető́k etikus vonásairól. S hogyan kapcsolódik ez az Ipar 4.0 kihívásaihoz? A választ onnan közelíteném meg, hogy az új technológiák megjelenése mellett (amelyek már önmagukban is magukban hordoznak etikai kérdéseket), ezen új kihívások között a vezető figyelmének fókusza továbbra is részben az alkalmazottak felé irányul. Amennyiben ő maga etikus, megfelelő példát mutat beosztottjainak, ezzel dolgozóit is etikus magatartásra ösztönzi, ami a vállalat számára több szempontból is versenyelőnyt biztosít, mind a terméket/szolgáltatások piacán, mind pedig a munkaeröpiacon. Tanulmányommal fel szeretném tehát hívni a vezetők, menedzserek figyelmét arra, hogy az új technológiák és az emberi tényező együttesen hozzák meg az új sikereket, s hogy ennek egyik lehetséges útja az, hogy tudatosan etikusan vezetik cégüket, etikus szervezeti kultúrát alakítanak ki.
\end{abstract}

Abstract. In this study I deal with the ethical leadership. I give an insight into the approaches of ethical leadership, give a literature review on the concept of ethical leadership, and introduce the measurement methods used in the most important empirical researches related to this topic. I also try to report on the first results of my research (I plan to describe features of Hungarian leaders based on a smaller sample). How does this relate to the challenges of Industry 4.0? I give the answer from the fact that, with the advent of these new technologies (which in themselves have ethical questions), among these new challenges, the focus of the manager's attention will continue to be partly on their employees. If they set an ethical example for their subordinates, they encourage their employees to act ethically, which gives the company a competitive edge in many ways, both in the product/service market and in the labor market too. So, with my study, I would like to draw the attention of executives and managers to the fact that new technologies and the human factor together bring new successes, and that one possible way of doing this is by consciously managing their company ethically and developing an ethical organizational culture.

\section{Bevezetés}

Napjaink vezetői és menedzserei újabb és újabb kihívásokkal néznek szembe munkájuk során. Ezen kihívások közül pusztán csak egy, hogy etikus magatartást tanúsítsanak, ugyanakkor ezt tőlük számos piaci szereplő elvárja. Az egész szervezet etikus megjelenése múlik a vezetők etikai attitűdjein, hiszen az ő értékrendjük kivetül a szervezet valamennyi tagjának értékrendjére és magatartására egyaránt. 
Amennyiben a vezető számára az etikus viselkedés fontos és követendő, akkor dolgozói is hasonlóan gondolkodnak és cselekednek, ellenkező esetben egyikük sem cselekszik etikusan. Éppen ezen elvárások, illetve hatások miatt irányult a figyelmem az etikus vezetői magatartás felé.

Ebben a tanulmányban áttekintem az etikus vezetés fogalmát, illetve megismertetek az olvasóval néhény nemzetközi empirikus kutatás során alkalmazott módszertani eszközt is. Cikkem végén pedig egy saját empirikus kutatás első eredményeiről számolok be.

\section{Az etikus vezetés fogalmi meghatározása}

Az etikus vezetés fogalmával összefüggésben Burns [1] megközelítéséből indulnék ki, aki a transzformációs vezetés modelljének megalkotása mentén hívta fel talán elsőként a figyelmet arra, hogy a vezető közös értékek követése mentén is menedzselheti, irányíthatja beosztottjai munkáját a szervezeti célok irányába. Ezzel szemben áll a tranzakciós vezetői magatartás, aki pozíciójában mondhatni mindössze adok-kapok folyamattá egyszerűsíti le a beosztottal való kapcsolatát: a dolgozó elvégzi a munkát, melyet ő az ösztönzési rendszer elemei segítségével ellentétez. Lényegében tehát arról van szó, hogy az önérdekből történő cselekvések helyett az értékek által vezérelt magatartás jelenik meg. Míg a tranzakciós vezető „üzletet köt” a beosztottal, addig a transzformációs vezető önmagát és beosztottjait is megváltoztatja a magasabb rendű, általános emberi célok irányába, miközben a szervezeti célok is megvalósulnak.

Egy másik szemlélet jelenik meg Trevino és szerzőtársai [2 és 3] munkájában, akik a morális személy és morális menedzser fogalmait különítették el. Kutatásaik során egyrészt megpróbálták azonosítani a morális személy tulajdonságait (őszinteség, megbízhatóság, igazságosság stb.), másrészt felhívták a figyelmet arra, hogy a morális menedzser ennél többet jelent: ez lényegében a vezető proaktív erőfeszítéseiben jelenik meg, annak érdekében, hogy a követők etikus és etikátlan magatartását befolyásolja. Ez határozottan megjelenik annak módjában, ahogyan az etikus vezető például kommunikál beosztottjaival vagy ahogyan jutalmazza őket.

A társadalmi felelősségvállalással kapcsolatban neves kutató, Caroll is foglalkozik az etikus, illetve morális vezető fogalmával [4]. Az ő megközelítése szerit a vezető magatartása etikai szempontból három féle lehet: morális, amorális és immorális. Az immorális vezető valójában úgy cselekszik, hogy figyelmén kívül esnek az etikai szempontok, még a törvényeket is megkerülhetőnek tartja. Az amorális vezető csak a jogot tartja iránytűnek, etikai szempontokat azonban még ő sem mérlegel döntései során. A morális vezető azonban már nem csak a jogot, törvényeket, de az ezen túlmutató, etikus értékrendet is követi, felelősnek tartja magát a szervezet érintettjeinek irányába.

Egy másik érdekes megközelítés, ami igen közel áll az etikus vezetéshez, a szolgáló vezetés szemlélete. Ezzel a fogalommal először Greenlaf 1970-es munkájában [5] találkozhattunk, ahol azt írja: „szolgálni a követőket a vezető elsődleges felelőssége és az etikus vezetés lényege” [5]. Spears 1995-ben [6] részletes áttekintést adott, milyen tulajdonságokkal kell rendelkeznie a szolgáló vezetőnek: figyelem, empátia, gyógyítás, tudatosság, meggyőződés, felfogás, előrelátás, gondnokság, elkötelezettség az emberek fejlődése iránt, közösségépítés. Ezeket a tulajdonságokat Barbuto és Wheeler [7] egészítette ki az elhivatottsággal, mint alapvető jellemvonással. 
Az etikus vezetéssel kapcsolatban Yukl [8] autentikus és spirituális vezetői megközelítését érdemes még megismernünk. Az autentikus vezető két legfontosabb vetülete a következetesség (saját szavai, tettei és értékrendje mentén) és a beosztottakkal kiépített kapcsolat minőségének javítása (például a bizalom tekintetében). A spirituális vezetés Yukl felfogásában szintén kettős jelentéstartalommal bír: részben utal arra, hogy a spirituális vezető számára a munka önmagában is értéket képvisel, részben pedig arra vonatkozik, hogy számára a „közösség mindenekelőtt” elv megvalósítása a cél, azaz egész tevékenységét hivatásként fogja fel [8].

A kifejezetten etikus vezetés fogalmakkal kapcsolatban hármat emelnék ki a szakirodalomból. Elsőként Kanungo meghatározását, amely azt mondja ki, hogy az etikus vezető „elkötelezett olyan cselekvések és magatartásformák irányába, amelyek mások érdekeit szolgálják és egyúttal tartózkodik attól, hogy másoknak kárt okozzon" [9]. Khuntia és Suar 2004-ben az etikus vezetés megnyilvánulását inkább a következetességben látják, azaz, hogy a morális elvek egyidőben jelennek meg a vezető hitében, értékrendszerében és viselkedésében, továbbá elkötelezettek a magasabb rendű célok, a körültekintés, a büszkeség, a türelem és a kitartás területén [10]. A legismertebb és talán legtöbbször hivatkozott fogalom a Brown, Treviño és Harrison kutatócsoporthoz kötődik, akik úgy fogalmaznak, hogy az etikus vezetés az alkalmazottakkal szembeni becsületesség és méltányos bánásmód, illetve az etikai normák követését jelenti [11].

Az 1. táblázatban összefoglaló áttekintés olvasható a spirituális, az autentikus és a transzformációs vezetésről: miben hasonlítanak az etikus vezetéshez, illetve miben különböznek az etikus vezetéstől [12]. Megismerve az összehasonlítás részleteit, láthatjuk, hogy az etikus vezetés leginkább az autentikus és a transzformációs vezetéshez áll legközelebb, a spirituális vezetés kevesebb hasonlóságot, ugyanakkor több eltérést is mutat.

\begin{tabular}{|c|c|c|}
\hline & Hasonlóságok az etikus vezetéssel & $\begin{array}{l}\text { Különbségek az etikus } \\
\text { vezetéshez képest }\end{array}$ \\
\hline Autentikus vezetés & $\begin{array}{l}\text { Tekintetbe venni mások érdekeit } \\
\text { (altruizmus) } \\
\text { Etikus döntéshozatal } \\
\text { Becsületesség } \\
\text { Példaképként szolgálni }\end{array}$ & $\begin{array}{l}\text { Az etikus vezetők jobban } \\
\text { hangsúlyozzák az erkölcsök } \\
\text { mentén való befolyásolást } \\
\text { (tranzakciós megközelítésben) és } \\
\text { az „egyéb” szempontok szerinti } \\
\text { tudatosságot. } \\
\text { Az autentikus vezető a } \\
\text { hitelességre és az önazonosságra } \\
\text { is fókuszál. }\end{array}$ \\
\hline Spil & $\begin{array}{l}\text { Tekintetbe venni mások érdekeit } \\
\text { (altruizmus) } \\
\text { Becsületesség } \\
\text { Példaképként szolgálni }\end{array}$ & $\begin{array}{l}\text { Az etikus vezetők jobban } \\
\text { hangsúlyozzák az erkölcsök } \\
\text { mentén való befolyásolást. } \\
\text { A spirituális vezetők jobban } \\
\text { hangsúlyozzák a jövőképet, az } \\
\text { abba vetett reményt/hitet; a } \\
\text { munka számukra hivatás. }\end{array}$ \\
\hline $\begin{array}{l}\text { Transzfol } \\
\text { vezetés }\end{array}$ & $\begin{array}{l}\text { Tekintetbe venni mások érdekeit } \\
\text { (altruizmus) } \\
\text { Etikus döntéshozatal } \\
\end{array}$ & $\begin{array}{lccr}\text { Az } \quad \text { etikus } & \text { vezetők } & \text { jobban } \\
\text { hangsúlyozzák } & \text { az } & \text { etikai } \\
\text { sztenderdeket } & \text { és } & \text { az } & \text { erkölcsök } \\
\end{array}$ \\
\hline
\end{tabular}




\begin{tabular}{|l|l|l|}
\hline $\begin{array}{l}\text { Becsületesség } \\
\text { Példaképként szolgálni }\end{array}$ & $\begin{array}{l}\text { mentén való befolyásolást } \\
\text { (tranzakciós megközelítésben). } \\
\text { A transzformációs vezetők jobban } \\
\text { hangsúlyozzák a jövőképet, az } \\
\text { értékeket és a szellemi ösztönzést } \\
\text { (pla a kreativitás és az } \\
\text { innovativitás irányába). }\end{array}$ \\
\hline
\end{tabular}

1. táblázat Az etikus vezetéssel rokon fogalmak áttekintése [12]

Az etikus vezetés definiálási lehetőségeinek bemutatása után áttérek a mérési lehetőségek ismertetésére.

\section{Az etikus vezetés mérési lehetőségei}

Ebben a fejezetben az etikus vezetés területén alkalmazott mérési módszerek bemutatása a cél. Előre kell bocsátanom, hogy bármilyen értékelési módszert használunk is, törekedni kell arra, hogy ne csak a vezető értékelje önmagát etikusságát megítélendő, hiszen az önértékelés nagy eltéréseket mutat mások értékeléséhez képest. A beosztottak valószínűleg pontosabb értékelést adnak a vezető etikus mivoltáról, különösen, ha együtt dolgoznak a vállalati müködés során, ha láthatják, hogyan bánik másokkal vezetőjük, illetve ha betekintést kaphatnak arra vonatkozóan is, hogy a döntéshozatali folyamatban mérlegeli-e az etikai szempontokat. Ugyanakkor a beosztottak esetében is előfordul, hogy ítéletük a vezetőről torzított, hiszen más értékrendet képviselhetnek vezetőikhez képest, illetve függő helyzetükből adódóan is eltérhet a valós és a kinyilvánított véleményük. Annak érdekében, hogy teljes képet kapjunk egy vezetőről, beosztottjain túl kikérhetjük az üzleti partnerek, ügyfelek és egyéb érintettek véleményét is. Mindezek után nézzük meg, milyen módszerek állnak a rendelkezésünkre, ha empirikus kutatást tervezünk ezen a területen.

A 2. táblázatban rövid összefoglalást találunk arra nézve, hogy mely szerzők, milyen mérési módszereket, skálákat dolgoztak ki, s azokban milyen változók mentén próbálták felmérni a vezetők etikus magatartását. Az áttekintő táblázat Chikeleze 2014-es munkája alapján készült [13]. Láthatjuk, hogy az első mérési eszköz 1998-ban született meg Craig és Gustafson munkásságának eredményeképpen [14]. Ők főleg negatív irányú megfogalmazás mentén vizsgálták a vezetők magatartását, $s$ azt is tudjuk, hogy a lehetséges magatartás és nem a megfigyelt magatartás felmérésére törekedtek. Ezzel szemben Brown és Treviño 2005-ben már pozitív irányú megfogalmazásokat használtak, s arra voltak kíváncsiak, hogy vajon a követők szerint rendelkezik-e a vezető az adott tulajdonságokkal [11]. 2010-ben Riggio és kutatótársai egy igen fontos dologra hívta fel a figyelmet: bárki is az értékelő a kérdőívek kitöltése során, felléphet a halo-effektus, mint észlelésbeli torzítás, ennek elkerülése érdekében a $360^{\circ}$-os értékelést javasolják a kutatások során alkalmazni [15]. Kalshoven és munkatársai esetében topmenedzsereket vizsgáltak etikus magatartásuk vonatkozásában, mérési skálájukban pozitív és negatív megfogalmazások egyaránt szerepelnek, ami azonba meg is zavarhatja a kitöltőket a válaszadáskor [16]. Az ő esetükben azt is láthatjuk, hogy az etikus vezetéshez közvetlenül nem kapcsolódó tulajdonságokat is próbáltak feltárni (pl. megosztott hatalom, tisztázott szerepek), ezen tényezők megjelenése arra a tényre is utalhat, hogy magának az etikus vezetésnek sem létezik egy mindenki által elfogadott, egységes meghatározása. 
Yukl és társai 2010-ben alkották meg az ELQ skálát [8 és 17], amely az ELS (Ethical Leadership Scale), illetve az ELWQ (Ethical Leadership Work Questionnaire) skálákkal egyetemben a leginkább ismert mérési eszköz. Yukl kutatócsoportja korrelációs kapcsolatokat vizsgált a meghatározó változók és az etikus magatartás vonatkozásában, de nem törekedtek az ok-okozati összefüggések feltárására (erre maga a módszer sem alkalmas). A Korábbi kutatókhoz hasonlóan ők is felhívták a figyelmet arra, hogy egy vezetôt több beosztott véleményezzen annak érdekében, hogy minél inkább valós képet kapjunk a vezető etikus magatartását illetően. Érdemes tudnunk azt is, hogy a Yukl féle kutatás során nem mértek más rokon vezetési stílust (pl. transzformációs vezetési stílust), ők az etikus vezetői magatartás vizsgálataira szűkítették le elemzéseiket.

\begin{tabular}{|c|c|c|c|}
\hline Év & Mérési eszköz megnevezése & Szerzők & Mért változók \\
\hline 1998 & $\begin{array}{l}\text { Perceived Leader Integrity } \\
\text { Scale (PLIS) }\end{array}$ & Craig and Gustafson [14] & $\begin{array}{l}\text { Megbízható } \\
\text { Előzékeny } \\
\text { Önközpontú } \\
\text { Becsületes } \\
\text { Gonosz } \\
\end{array}$ \\
\hline 2005 & Ethical Leadership Scale (ELS) & $\begin{array}{l}\text { Brown, Treviño, and } \\
\text { Harrison [11] }\end{array}$ & $\begin{array}{l}\text { Igazságos } \\
\text { Megbízhító } \\
\text { "Do the right thing" }\end{array}$ \\
\hline 2010 & $\begin{array}{l}\text { Leadership Virtues } \\
\text { Questionnaire (LVQ) }\end{array}$ & Riggio, Zhu and Reina [15] & $\begin{array}{l}\text { Körültekintő } \\
\text { Állhatatos } \\
\text { Mértékletes } \\
\text { Igazságos }\end{array}$ \\
\hline 2011 & $\begin{array}{l}\text { Ethical Leadership Work } \\
\text { Questionnaire (ELWQ) }\end{array}$ & $\begin{array}{l}\text { Kalshoven, Den Hartog, } \\
\text { and De Hoogh [16] }\end{array}$ & $\begin{array}{l}\text { Igazságos } \\
\text { Tisztesség } \\
\text { Etikai iránymutatás } \\
\text { Emberközpontúság } \\
\text { Megosztott hatalom } \\
\text { Tisztázott szerepek } \\
\text { Elkötelezettség a } \\
\text { fenntarthatóság iránt }\end{array}$ \\
\hline 2013 & $\begin{array}{l}\text { Ethical Leadership } \\
\text { Questionnaire (ELQ) }\end{array}$ & $\begin{array}{l}\text { Yukl, Mahsud, Hassan, and } \\
\text { Prussia [17] }\end{array}$ & $\begin{array}{l}\text { Őszinteség } \\
\text { Igazságosság } \\
\text { Tisztesség } \\
\text { Példamutatás } \\
\text { Elkötelezettség az értékek } \\
\text { iránt }\end{array}$ \\
\hline
\end{tabular}

2. táblázat. Az etikus vezetéssel kapcsolatban alkalmazott mérési skálák áttekintése [13]

Összefoglalásként elmondhatjuk, hogy a fent bemutatott mérési eszközök eltérést mutatnak célkitűzésekben, az alkalmazott skálák megfogalmazásában, szemléletmódjukban és terjedelmükben egyaránt. Ebből kifolyólag az e területen kutató kollégák számára több lehetőség is rendelkezésre áll, hogy milyen formában valósítják meg empirikus elemzéseiket. 


\section{Első kutatási eredmények}

Az általam tervezett kutatás célja, hogy a magyar vezetők magatartásának etikai oldalát felmérjem, lehetséges különbségeket keresve nemek, tulajdonosi struktúra és vállalati méret alapján. A kérdőív kitöltésére munkaviszonnyal/munkatapasztalattal rendelkezőket kerestem, keresek fel.

Kutatásomhoz Yukl és szerzőtársai által 2013-ban megalkotott ELQ (Ethical Leadership Questionnaire) skálát használom [17]. A kérdőív 15 állítást tartalmaz, amelyet Likert formátumú 6 pontos skálán kell értékelni (ahol 1-es érték az Egyáltalán nem ért egyet, míg a 6-os érték a Teljes mértékben egyetért választ jelöli). Az elemzés során átlagot, szórást számolhatunk, illetve elegendő elemszám esetén magasabb szintű statisztikai módszerekkel is elemezhető az adatbázis.

Az adatfelvétel 2019. őszén kezdődött, a konferencia napjáig azonban még csak egy meglehetősen kis minta vált elemezhetővé, így az elemzés és a megállapítások köre is korlátozott. Az addig beérkezett kérdőívek száma 21 darab, melyből 20 darab volt értékelhető. Az első összesített eredményeket a 3. táblázat foglalja össze. Jelen esetben a kis adatbázis mindössze ezeket a számításokat teszik lehetővé. A kérdőívek kitöltésére első körben a Debreceni Egyetem Gazdaságtudományi Karának levelező képzésben részt vevő hallgatóit kértem meg, közülük is azokat, akik rendelkeznek munkaviszonnyal, munkatapasztalattal, hiszen vezetői magatartás értékelésére csak ezen feltétel teljesülése mellett van lehetőség.

A táblázat soraiból láthatjuk, hogy a válaszadók szerint az etikus vezetői magatartás leginkább az őszinteséggel, becsületességgel azonosítható, kiegészítve ezt azzal, hogy a felelősségvállalás terén is lépéseket tesz, ha etikátlanság cselekedetet tapasztal, ezen első három állítás esetében a válaszok átlagértéke a 4,5-es érték felett van. Érdemes azonban a lista végére is pillantanunk: azt, hogy a vezető mások érdekeit sajátjai elé helyezze az eddigi válaszadók nem tartották fontosnak (az átlagérték még a 3,5-es értéket sem érte el).

\begin{tabular}{|ll|c|c|}
\hline \multicolumn{1}{|c|}{ Értékelendő állítás } & \multicolumn{2}{c|}{ Válaszadók értékelése } \\
\cline { 2 - 4 } & Átlag & Szórás \\
\hline 1. & $\begin{array}{l}\text { Az őszinteséget és az becsületességet } \\
\text { fontos személyes értéknek tartja. }\end{array}$ & 4,86 & 1,42 \\
\hline 2. & $\begin{array}{l}\text { Őszinte és megbízható atekintetben, hogy } \\
\text { megmondja az igazat. }\end{array}$ & 4,71 & 1,65 \\
\hline \multirow{2}{*}{3.} & $\begin{array}{l}\text { Felelősségrevonhatónak tartja a tagokat az } \\
\text { etikus gyakorlatért az elvégzett munka } \\
\text { során. }\end{array}$ & 4,67 & 1,59 \\
\hline 4. & $\begin{array}{l}\text { Következetesen tartja magát az általa } \\
\text { kinyilvánított értékekhez. }\end{array}$ & 4,38 & 1,63 \\
\hline 5. & $\begin{array}{l}\text { Megbízható az ígéretek és a } \\
\text { kötelezettségvállalások tekintetében. }\end{array}$ & 4,25 & 1,45 \\
\hline 6. & $\begin{array}{l}\text { Tisztán kommunikálja az etikai } \\
\text { standardokat a tagok felé. }\end{array}$ & 1,61 \\
\hline 7. & $\begin{array}{l}\text { Ragaszkodik ahhoz, hogy tisztességesen és } \\
\text { etikusan cselekedjen, még akkor is, ha ez } \\
\text { nem könnyú. }\end{array}$ & 4,24 & 1,74 \\
\hline
\end{tabular}




\begin{tabular}{|c|c|c|c|}
\hline & $\begin{array}{l}\text { Erős elkötelezettséget mutat az etikus és } \\
\text { morális értékek iránt. }\end{array}$ & 4,10 & 1,51 \\
\hline & $\begin{array}{l}\text { Elismeri a hibákat és vállalja a felelősséget } \\
\text { értük. }\end{array}$ & 4,05 & 1,53 \\
\hline & $\begin{array}{l}\text { Példát mutat az etikus magatartásra } \\
\text { döntései és cselekedetei révén. }\end{array}$ & 4,00 & 1,55 \\
\hline & $\begin{array}{l}\text { Ellenzi az etikátlan gyakorlatokat még } \\
\text { akkor is, ha azok javítanák a teljesítményt. }\end{array}$ & 3,86 & 1,71 \\
\hline & $\begin{array}{l}\text { Igazságos és elfogulatlan, amikor a tagok } \\
\text { számára a feladatokat kijelöli. }\end{array}$ & 3,67 & 1,80 \\
\hline 13. & $\begin{array}{l}\text { Igazságos és objektív a tagok } \\
\text { teljesítményértékelése és jutalmazása } \\
\text { során. }\end{array}$ & 3,65 & 1,66 \\
\hline & $\begin{array}{l}\text { Példakép az adakozás és az önfeláldozás } \\
\text { terén. }\end{array}$ & 3,57 & 1,69 \\
\hline & $\begin{array}{l}\text { Mások érdekeit saját maga érdekei fölé } \\
\text { helyezi. }\end{array}$ & 3,38 & 1,80 \\
\hline
\end{tabular}

3. táblázat. Saját adatgyüjtés elemzése (2019)

Ismét hangsúlyoznunk kell azonban, hogy ez a rendelkezésre álló minta kis elemszámú, így mélyebb elemzésre nem ad lehetőséget, a megállapításokkal is óvatosnak kell lenni. Bízunk benne, hogy a folyamatosan beérkező kitöltött kérdőívek további elemzéseket tesznek majd lehetővé.

\section{Zárszó}

Tanulmányomban az etikus vezetés témakörével foglalkoztam. Elsőként áttekintettem az etikus vezetéssel összefüggésbe hozható vezetői magatartásformákat, majd próbáltam konkrétan az etikus vezetés fogalmát bemutatni a rendelkezésre álló és feldolgozott szakirodalom segítségével. Megállapíthatjuk, hogy mint sok már területen, ezen témakörben sem születtek még meg egységes és elfogadott definíciók, sem az etikus vezetés fogalmát illetően, sem annak vonatkozásában, hogy is lehetne legjobban mérni, hogy egy vezető mennyire etikus tevékenysége során. Azt gondolom, ugyanakkor, hogy éppen ez adja meg a lehetőségét annak, hogy több szempontból is körbejárható, vizsgálható legyen kutatásainkban ez a kérdéskör. Én magam is elindítottam egy empirikus kutatást ebben a témakörben, felhasználva a Yukl által megalkotott ELQ (Ethical Leadership Questionnaire) mérési skálát, de az elemzésekből levonható következtetések még erősen korlátozottak. Elképzeléseim szerint a jövőben - nagyobb adatbázis alapján - lesz lehetőségem mélyebb elemzésekre, tovább a nemzetközi adatokkal való összehasonlításra is.

\section{Hivatkozások}

[1] Burns, J. M., Leadership, New York, 1978, Harper \& Row

[2] Treviño, L. K. - Hartman, L. P. - Brown, M., Moral person and moral manager: How executive develop a reputation for ethical leadership, 2000, California Management Review, 42, 128142. 
[3] Treviño, L. K. - Brown, M. E. - Hartman, L. P., A qualitative investigation of perceived executive ethical leadership: Perceptions from inside and outside the executive suite, 2003, Human Relations, 55, 5-37.

[4] Caroll, A., The Pyramid of Corporate Social Responsibility: Toward the Moral Management of Organisational Stakeholders, 1999, Business Horizons, 7-8, 46-47.

[5] Greenleaf, R. K., Essentials of servant leadership, In: Spears, L. C. - Lawrence, M. (Eds), Focus on leadership: Servant-leadership for the 21st century, 1970/2002, Hoboken, 19-25.

[6] Spears, L. C., Reflections on leadership: How Robert K. Greenleaf's theory of servant- leadership influenced today's top management thinkers, 1995, New York, John Wiley

[7] Barbuto, J. E., - Wheeler, D. W., Becoming a servant leader: Do you have what it takes?, 2002, NebGuide G02-1481-A. Lincoln: University of Nebraska, Nebraska Cooperative Extension

[8] Yukl, G., Leadership in Organizations, 2010, Seventh Edition, Pearson, New York

[9] Kanungo, R. N., Ethical Values of Transactional and Transformational Leaders, 2001, Canadian Journal of Administrative Sciences, 18, 257-265.

[10] Khuntia, R. - Suar, D., A Scale to Assess Ethical Leadership of Indian Private and Public Sector Managers, 2004, Journal of Business Ethics, 49, 13-26.

[11] Brown, M. E. - Treviño, L. K. - Harrison, D. A., Ethical leadership: A social learning perspective for construct development and testing, 2005, Organizational Behavior and Human Decision Processes, 97, 117-134.

[12] Brown, M. E. - Treviño, L. K., Ethical leadership: A review and future directions, 2006, The Leadership Quarterly, 17, 6, 595-616.

[13] Chikeleze, M. C., Validation of the Ethical Leadership Style Questionnaire (ELSQ), 2014, Benedictine University, ProQuest Dissertations Publishing, No. 3584797

[14] Craig, S. B., - Gustafson, S. B., Perceived leader integrity scale: An instrument for assessing employee perceptions of leader integrity, 1998, The Leadership Quarterly, 9, 127-145.

[15] Riggio, R. E. - Zhu, W. - Reina, C., Virtue-Based measurement of ethical leadership: The Leadership Virtues Questionnaire, 2010, Consulting Psychology Journal: Practice and Research, 62, 4, 235-250.

[16] Kalshoven, K. - Den Hartog, D. N. - De Hoogh, A. H. , Ethical leadership at work questionnaire (ELW): Development and validation of a multidimensional measure, 2011, The Leadership Quarterly, 22, 1, 51-69.

[17] Yukl, G. - Mahsud, R. - Hassan, S. - Prussia, G. E., An improved measure of ethical leadership, 2013, Journal of Leadership \& Organizational Studies, 20, 1, 38-48. 